\title{
Improving political science degree programmes in the twenty-first century
}

\author{
Tashfeen Ahmad \\ Project Management Office, University of the West Indies, Mona, Jamaica
}



231

Received 25 February 2019 Revised 4 August 2019 Accepted 2 September 2019

\begin{abstract}
Purpose - This paper aims to examine the actions lecturers, universities and their administrators can take in improving and making political science undergraduate degrees more relevant in the twenty-first century. This paper will reflect on specific measures undertaken by institutions globally to equip students with unique skills to enhance the value and relevance of their programmes in the context of an increased technologically driven environment.

Design/methodology/approach - This paper uses a qualitative approach to the review of the literature with implications for practice in examining how universities globally are applying strategies in raising students' skill levels to enhance future workplace value. A review of select institutions obtained from the Times Higher Ranked (2019) universities was used in identifying best practices to prepare a political science student for better employability.

Findings - Contrary to prevailing opinions, a huge skills gap exists for filling the demand for twenty-first century political science-related careers in the public and private sector. The attainment of twenty-first century skill sets and the deployment of technology-driven teaching and learning methods are vital elements in unlocking the value of political science education and providing students with opportunities to advance their professional and career objectives.

Originality/value - Higher education institutions need to reconsider their strategies in the delivery of political science degrees, bearing in mind the increased use of technology and innovative teaching practices. This paper offers insight into how to tailor an exciting and relevant political science programme for the future of work.
\end{abstract}

Keywords Political science, Value, Technology, Future, Skills, Best practices, Higher education, 21st century, Political science

Paper type Research paper

\section{Introduction}

Political Science can be considered to be a broad discipline and is often under appreciated by employers because of the perceived lack of transferrable skills and also because it is not highly regarded as some of other vocational disciplines at the undergraduate level. As stated by Columbia University's Bernard College Department of Political Science, this discipline explores questions about power, what it is and who exercises it.

More importantly, the discipline encompasses the study of processes, policies and institutions of various political systems and helps train students in critical thinking,

(C) Tashfeen Ahmad. Published in Review of Economics and Political Science. Published by Emerald Publishing Limited. This article is published under the Creative Commons Attribution (CC BY 4.0) licence. Anyone may reproduce, distribute, translate and create derivative works of this article (for both commercial and non-commercial purposes), subject to full attribution to the original publication and authors. The full terms of this licence may be seen at http://creativecommons.org/licences/by/4.0/ legalcode

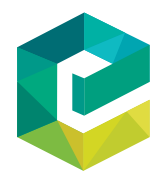

Review of Economics and Political
Science
Vol. 5 No. 3,2020
pp. $231-247$
Emerald Publishing Limited
$2356-9980$
DOI $10.1108 /$ REPS-02-2019-0023 
REPS

5,3

232

rigorous and methodical analysis to enable them in addressing practical political issues and challenges, while contributing to the wider society and community. Students also seek to attain a political science degree to prepare them for a wide range of careers in the public sector, private business, international relations organisations, non-profit organisations and academia.

However, within the twenty-first century context, many have begun to question the value and relevance of a political science degree. There is the criticism that the discipline is highly theoretical in approach emphasising subjects such as history, philosophy and political thought, with less emphasis being placed on the use of practical skills.

In addition, this discipline does not sufficiently provide students with a clear explicit professional and career path. In this regard, higher education institutions (HEIs) need to rethink their strategies about how best to convey the potential value and derive opportunities from the attainment of a political science degree. One suggestion is to emphasise the transferrable and employability skills component in filling the gap in demand of twenty-first century jobs. The employability agenda is emerging as an extremely important issue within the political science curriculum of HEIs given increased emphasis on career development and advancement prospects (Hale, 2008). Students also have a part to play in demonstrating and showcasing the value and relevance of their degrees in these new career areas.

In this paper, we examine the various strategies higher education institutions can pursue in making political science relevant in the twenty-first century. This is an imperative for universities given the demand for special skill sets they will need for the future of work and Industry 4.0. We reflect on specific measures undertaken by institutions globally to equip students with unique skills to enhance the value and relevance of their programmes in the context of an increased technologically driven environment.

This paper embarks on a qualitative approach to the review of the literature with implications for practice in examining how universities globally are applying strategies in raising students' skill levels to enhance future workplace value. It begins first by tracing the development of various models, theoretical frameworks pertaining to best practice approaches towards changes in political science curriculum over recent decades.

Then, it provides recommendations for practical implementation of approaches to increasing the value of the discipline via the acquisition of training and skills, innovative learning pedagogies and the deployment of targeted career and employability initiatives.

A review of select institutions obtained from the Times Higher Ranked (2019) universities was then used in identifying best practices and evaluating the extent to which institutions are sufficiently preparing current political science students for better employability in the context of twenty-first century job setting and the future of work.

\section{Literature review}

Best practice models of curriculum change in political science discipline

Currently there has been increased dialogue taking place on how tertiary institutions can advance on preparing students of Political Science for the world of work. It is important to recognise that the world is constantly changing and there is a need to adapt to these changes and to prepare students for the future of work (Ahmad, 2015). For instance, there is the consideration regarding what a modern political science curriculum programme should entail for success. Franco (2018) in his most recent assessment of the bachelor's degree programme emphasises the need for institutions to develop and hone students' "social scientific skills and practical skills". He concludes that it is important to have a combination of research and analytical skills. 
The view is advanced that for students to be properly prepared for work, both research and analytical components of the curriculum must be enhanced. Institutions will have to refocus on the training in the five core competencies including soft skills, technology and data skills analysis. In terms of teaching and delivery, universities must consider other options rather than instructor led approaches.

Design elements which incorporate aspects of quantitative, knowledge and information gathering along with the application, practical oriented approach supported by the use of social scientific skills and the ability to analyse and apply political science principles to solving current issues should be focus of curriculum changes. In effect, the design of all political science degree programmes should be geared towards the training of both researchers and analysts to learn the "science and practice" of politics to prepare them for twenty-first century career opportunities in international relations, public policy and private sector (Franco, 2018).

In their "audit" and assessment on the state of political science curriculum at United Kingdom higher education institutions, Clark and Martin (2016) identified the importance of the role which transferrable skills attainment have in making students more employable and marketable in the present context. Their study suggests that while significant efforts and progress have been made in recent years, more work needs to be done to raise awareness of these approaches especially with online delivery modes of instruction.

For instance, contextual factors or issues impacting current skills and employability agenda must be in the forefront of curriculum design. The use of surveys and information systems to track employment levels after graduation, the move towards a more business oriented approach by institutions to deliver educational products and services demanded by stakeholders and students alike, along with the increasing drive towards globalisation and internationalisation are important factors identified as creating the impetus for change in the approach to employability skills training (Clark and Martin, 2016).

In addition, their study also identified that skill shortage has put the skills agenda in the forefront of UK HE policy. It concluded that real economic development is a function of the provision and acquisition of high quality skills training. In defining the types of skill sets and in the context of employability, data gathering, analytical and synthesis, selfmanagement and reflection, awareness, teamwork, collaboration, communication and numeracy, IT skills were identified as top priority driving employability.

However, critics have raised objections to the driving of this agenda as the major thrust for curriculum change in social science and political science disciplines. For example, there is the more radical view that political science as a discipline has witnessed a serious decline in rigorous scholarly engagement in the current neo-liberal setting. Such an environment fosters or facilitates the "rise of careerism" (DiMaggio, 2018) with too much focus in higher education structure on career and personal pursuits at the expense of larger public outreach and social obligations.

Clark and Martin (2016) however respond to these concerns by asserting that transferrable skills are absolutely fundamental to the acquisition of modern education. The delivery modes of imparting such skills can range from internships and placements, assessment of policy-making assignments to study group work, communication and collaboration efforts, and the use of simulation role-plays to test negotiating and teamwork.

Therefore, HEIs need to rethink how they deliver employability transferrable skills training to students, with module guide delivery being the suggested approach to be integrated into curriculum. However, institutions need to communicate and increase the awareness levels of their employability and transferrable skills training agenda in a timely manner to students via the various delivery modes to ensure future impact and success. 
REPS

5,3

234
In a more recent review of the state of the American undergraduate political science degree curriculum, McClellan traces the development of various models of the curriculum in terms of structure, organisation and objectives used for studying this discipline.

The study brings into focus the crafting of frameworks after the assessment of recent American Political Science Association reports on the state of political science education in the context of twenty-first century learning. From a developmental perspective, political science has experienced four important phases notably referred to as the distribution, engagement, outcome and high impact based modes of curriculum changes over the past few decades.

For instance, distribution models of education are really based on distribution requirements meaning that such educational frameworks were essentially geared towards the delivery of political knowledge for practical use in the public service.

Increased criticism has led to the incorporation of critical thinking and analytical skills and the emergence of an associated "building block" model which relies on the use of a more structured approach supported by soft skills development and research oriented methods. However, the most important critical element missing in this early curriculum model was the need to have effective mechanisms to measure ability to prepare students' with job placement and readiness assessment outcomes.

Hence, we saw the development of Political Engagement Models. Such a framework went beyond the notion of internship programmes to incorporate clear objectives geared towards the training of students for civic involvement and leadership roles. As earlier implied in our review of the findings on UK programmes, critics have asserted that such programmes are devoid of student participation in political and civic affairs, in addition to the fact that there exists limited evidence of the impact of integrating political engagement programmes in HEIs (DiMaggio, 2018).

The development of the later Outcomes Based Model brings into question the sharper focus concerns regarding what the goals and learning delivery methods of political science ought to be. Some contend that it should be to advance the objectives of a "liberal education" while affording students real life practical global citizenship experience and career opportunities. On one hand, there is the recommendation that methodologies and delivery methods ought to concentrate on the provision of off campus internships, and exposure to political process scenarios.

However, others contend that HEIs need to focus their approach on providing solid training on the acquisition of core building block skills and competencies, such as critical thinking, analytical and application, in addition to measuring and assessing the extent to which these are obtained. The emergence of technology driven and innovative pedagogies has disrupted these models. Examples of these include online modes of delivery, competency based approaches and customised learning approaches. This has led to more "diversity" of the political science discipline and opinions surrounding curriculum objectives.

Hence, the development of high impact models emphasising political engagement. Here the focus is mostly on the acquiring high impact practical oriented learning experiences via the use of learning communities and groups, cross cultural exercises and projects to increase collaboration, interaction, team work, engagement, peer cooperation (Baranowski and Weir, 2011) and diversity skills. The overwhelming majority of HEIs agree that there must be continued focus on the development of core writing, researching and critical thinking skills. In addition, this should be supported with experiential learning experiences via internships and exposure to civic and political engagement projects. 
However, the following question arises: What about the future direction pertaining to the reform of the curriculum? The study suggests that current curriculum models reflect the persistence of the above models in one form or another with incremental changes, with the distribution model elements remaining the dominant framework for most Political Science curriculum structure. There still remains substantial resistance to change. The lack of incentives, poor institutional support mechanisms and pressing financial imperatives in the form of funding and budgetary challenges are viewed as serious constraints against any fundamental reforms (Sloam, 2008).

\section{Contextual factors impacting fall in value of political science degree}

Political science majors can be affected by adverse economic challenges faced by university. Their reduced employability can be explained through the theory of job-education matching. Matching education to employment is deemed important because it conjoins individuals to specific career prospects (Dezelan and Hafner, 2014). Based on the human capital theory, elements of training and experience are only second to the mode of education in the capacity to develop the mental skills of students which enables the matching process.

Due to an increase in the level of enrolment in post-secondary institutions, the value of education within this sphere has decreased. This has consequently led to an increase in the number of mismatches. Political science majors would then be compelled to take on other vocational priorities even those that are less valuable.

A second explanation can be that various disciplines studied in schools are categorised in either of the following dichotomous groups, that of hard-applied or soft-applied sciences. The disciplines that are characterised as soft applied such as sociology and political science are less regulated; because of this, there is no set dimension of careers for which these majors may fall.

To deal with this problem, universities have been taking strides to diversify and broaden the scope of degrees that can be selected by Political Science majors. This allows students to engage themselves across different subfields.

Globalisation and technological innovations has also created external barriers, which limit the employability of some graduates. These agents of change have created a significant shift that is not only visible in the agency of learning and the expectations of being educated, but also in the labour market especially in developed countries.

There has been a decrease in job opportunities in the public and private sector; which is usually filled by political science majors. The use of computerised machines encrypted with systemised instruction has reduced the value and supply for labour in certain fields. These global trends are further exacerbated by economic and financial downturns.

Additionally, Dezelan and Hafner (2014) put forward that nepotism has been a critical factor which has affected the employability of Political Science students. Studies conducted in France, Spain and Italy revealed that there are a lot of backdoor personal connections which have influenced the recruiting process for businesses. This occurs where the capabilities and the suitability of candidates are not measured based on a transparent meritocratic system but rather on relations and personal ties with recruiters. Family members and associates of the recruiters are usually given privilege over other candidates.

Notwithstanding that there are external influences and barriers affecting the employability of Political science, there is still a call for distinct changes to be made within curriculum to make this major more attractive and competitive on the job market. 
REPS

5,3

Practical approaches to enhancing the value of political science programmes

We have alluded to the suggestion that higher education institutions must rethink strategies to enhance the value proposition and potential benefits of a political science education (Johnson, 2016). Students, lecturers and university administrators need to recognise the value of political science and its huge potential for career advancement (Breuning et al., 2001). More importantly, political science departments need to sensitise, communicate and make aware the value of the degree and its attendant employability opportunities (Clark, 2011).

Breuning et al. (2001) asserted that it was not peculiar for quip remarks to be made regarding political science majors. These witty gestures are made at the expense of their limited exposure to practical skills which would land them in a career. This sentiment is shared across different universities. From a survey that was done to see how students of Political Science were being prepared for the world of work across two hundred and seventy-nine universities, Collins et al. (2012) concluded that most of the departments relating to field of study were not doing enough to adequately prepare their students.

Since then, progress has been made and the mechanisms and instruments adopted in the pedagogical efforts of learning institutions have been modified over time. Evidently, the instruments of conveying and gleaning knowledge that are used within the contemporary space, to some degree, differ from those used in the past.

To exemplify this point, Bournova (2008) revealed that within a traditional classroom setting the teacher-student interaction was minimal. Students were mere receptors of knowledge from instructors whom acted as repositories of knowledge. With this method, the process of teaching was not one of exchange as students were excluded from the process of conveying knowledge.

Conversely, with time instructors adopted a more facilitative role. This is done by monitoring collaborative and group engagements among students. Richards (2006) highlights that this method of teaching placed some of the onus on students for their own learning. Nackenoff (2014) posits that the level of preparation students of Political Science receive may be influenced by the institution they choose to enrol in. She put forward that liberal colleges which were relatively small were better able to prepare students of Political Science for the world of work than larger institutions, as instructors were more specialised within this field.

On the contrary, the essence of specialisation would have been lost or eroded with space within larger universities. Additionally, due to the larger bodies of students the studentuniversity relationship is less personal which creates a stretch for any discourse between the two. Faculty members also feel less incentivised to innovate tailored pedagogical methods for Political Science majors. Likewise, McCarthy and Anderson (2000) emphasises the need for more interactive sessions between students and lecturers. They noted that lectures are generally the central means of teaching university students; however, the size of these theatres does not facilitate much student-instructors joint discussion.

Therefore, students mostly engage in surface learning rather than gain in depth knowledge. Smaller classroom settings will make it easier for students to gain clarification and have one-one discussions. Additionally, it would be easier to tailor the teaching styles of lecturers to fit the unique learning styles of students within such a setting. Many universities have overemphasised their adoption in these outmoded measures for preparing university students of Political Science through establishing specialised faculties or departments and dedicating more time to individualised sessions between lecturers and students. 
The structured curriculum of the faculty of political science then can allow students to develop skills through their enrolment in various courses; notwithstanding that critical thinking, problem-solving and other similar skills are important within the world of work, but students also need to adopt practical skills. Theoretical based engagements such as reading or writing are insufficient in this capacity to equip students of Political Science with these skills, as they are not challenged to practically apply themselves which is a fundamental skill on the job market.

\section{Political science degree}

\section{Innovative pedagogical alternatives towards political science value enhancement}

Students feeling dissatisfied that their studies did not adequately prepare them for the future of work may not be a foreign sentiment to many political science majors as they grapple with the unknown regarding their place and the significance of their degree within the work sector.

It is important that universities make it their priority to adopt corrective initiatives to deal with the issue of better preparing their students of political science for the world of work. In some first-world countries, such measures have been introduced within tertiary institutions. In Europe, for example, universities have started putting more emphasis on the attainment of higher teaching qualifications for instructors. This is seen as a necessary tool to meet the desired learning objectives of students and for the passing on required skills that are recognised within the work place.

On the contrary, Ishiyama (2005) suggested that the curriculum of Political Science majors do not place sufficient emphasis on the advancements of skills and practical capabilities which are required to prepare students in the world of work. This incapacitation will adversely affect the transitional process of applying themselves within the workspace and inevitably affect their means of living.

There is an increase in the demand for skills and hands on training for Political Science students. It is not suggestive that theoretical based knowledge should be rejected because this provides students with a set of fundamental principles and guidelines on how to interpret the world in which they live, i.e. human behaviour. There needs to be some balance in the curriculum of Political Science major in this respect. The efforts and energies taken by the approaches of universities in getting Political Science majors "to know" should be equivalent to the efforts channelled towards getting them "to know how to".

The curriculum attached to Political Science is generally theoretical based. Students of this area are over engaged with topics pertaining to Comparative Politics, International Relations and Political Theory while there is little effort in engaging them with practical skills. This has become a growing concern regarding the competencies and capabilities, and thus the level of employability of such students.

Very few institutions take the initiative or adopt measures that will enhance and strengthen the job networking within and outside the institutions. This is very important for establishing connections of links to expand one's career prospects. It also helps students to interact with people with whom they may have similar vocational objectives. Preparing Future Faculty programme at some universities makes provisions for students to visit other colleges and universities to interact with other students and faculty members. Notably this process is relatively inexpensive to implement within university structures one as it could be aided with the use of social media sites such as Facebook. This is important to increase the employability of Political Science students and to make accessible to them the competitive world of the job market from an early stage. Additionally, more emphasis should be placed on sessions dedicated to resume preparation and mandatory internships to train and equip students with the practical skills. 
REPS

5,3

238

Similarly, the classroom setting should seek to mirror or reflect the work place in preparing students. The skills taught to students during their enrolment in tertiary level institutions were necessary but not only specific to the work place but also for life beyond that. By means of recognising that the extended purposes of the skills with which students are equipped, their significance in the lives of students becomes more visible.

The world is constantly changing through technological innovations. Teaching methods must not only correspond with these changes in society but also with how students respond to these changes. There have been alterations in the way in which students learn because of these technological innovations. The traditional modes of teaching inherently lose relevance and become ineffective. Lecturers of political science ought to develop the capacity to implement more creative ways to meet the emerging unique learning styles of students.

This can be achieved through a dramaturgical approach. This approach transforms the traditional classroom setting into a more innovative one, where lecturers are constantly creating new ways of relating to students in response to changes as they occur. This transformative process requires the collaborative and sustained efforts on the part of lecturers, faculty administrators and students to bring about significant and consistent change.

It is necessary for a stronger relationship to be built between instructors and employers. This interaction will facilitate more in-depth discourse around the skills that are to be taught and passed on to students to make them more competent, equipped and suitable employees. The inclusion of students will foster a student-university relationship which will make the concerns of students more accessible and transparent to universities. This way other conversations relevant to preparing students of Political Science for the world of work will take key priority.

However, Bok (2006) highlighted that lecturers and students have conflicting views as it relates to the importance of knowledge. Universities have the perception that knowledge is not a means to an end but an altogether end. Students on the other hand share a contrasting and challenging view that what is learnt should provide a means to an end. Therefore, the relevance of topics and lessons learnt is to bring immediate or long-term benefits to students.

This has affected students' willingness to learn a particular subject or topic. Many may engage with it for the mere passing of examinations. This position has led students to put a lot more emphasis on things from which they will earn gratification, rather than learning for expanding one's knowledge base. To attest to this, one could discuss the typical example where students often question the purpose of learning statistics and other advanced mathematical operations, regarding their career prospects.

Duch et al. (2001) option for a more problem-based approach to learning is a possible way university could respond to this. Traditionally, universities' presentations for the conveyance of knowledge to students are predominantly theoretical. The instruments of assessment reflect the same approach in that they merely test students' capacity to reiterate and recollect the information presented.

This approach does not challenge their apprehensive or reasoning capabilities. Drafting questions that will require student's application of knowledge would be a more effective means of evaluation. It will also challenge the students' willingness to learn. Creating concrete examples or real-life scenarios with which students can relate will have the benefit of spiking their interests.

The necessity of students learning statistical and scientific skills were emphasised by Hill and Myers (2014). It was noted that there is an increasing call for political science majors to be scientifically literate. This refers to the ability to capture, utilise and adopt 
mathematical, technological and scientific expressions and imperatives in one's modes of thinking. Hurd (1997) asserted that there are two types of curricula that are affiliated with science.

Firstly, the one taught in schools which conveys ideas relating to laws and theories to students and secondly the "lived curricula" where science is applied to interpret and solve issues. The National Science Foundation (NSF) Advisory Committee suggested that there needs to be re-education on how science is viewed by persons who are expected to pursue careers in non-scientific related fields. Universities need to highlight how science is valued within social dimensions.

Changes in the science curricula should involve more than just updates in physical sciences but there is a need for science to be used outside of the laboratory and within the socioeconomic and political domain of society. This transdisciplinary approach of intertwining scientific and social disciplines has increasingly been adopted in the process of addressing societal issues which include wellness and climate change.

Hill and Myers (2014) noted that much dedication is not made toward effecting this change of incorporating hard sciences within the domain of soft sciences. They noted that despite that social science, such as political science is not mathematically, technologically or scientifically based learning science was critical to the performance of students and also later, for some, in their services as political leaders. Applying science provides a more empirical, systematic and objective basis to explore or carry out enquiries.

Rathbun and Rathbun (2017) engage students in more policy-based researches in their courses. This helps students to develop the skills they would need to effect change in a practical and doable manner. Similarly, some universities emphasise conducting research studies in teaching Political Science major's skills which are vital within the work field. Studies show that students can garner more practical skills by conducting researches. The aim of Political science is to make students politically literate. This will help students to extend their analytical skills to understand the political world in which they live. The enhancements of skills in this respect are those germane to identifying research problems, critical thinking, problem solving, document and reporting. Students may also learn skills relevant to time and resource management.

Roulston and McCrindle (2018) referred to the enquiry stage or research in particular. They were of the view that it enables students to formulate tangible and empirical outputs. During this process, students will have to interact with the objects contained within their environment, their peers, organisations and other researchers to glean information and also to interpret the potential impact their study would have on them.

Research allows students to build on their innovative, communication and adaptive skills. These are great attributes and qualities to be possessed by any political science major who is constantly interacting with the world and observing/assessing contemporary issues of society. Additionally, students are engaged in what is termed as double loop learning. This describes the applied approach used by students to correct their downfalls in their research which will yield a different result.

These skills are key attributes because their relevance is not outmoded to students' learning, universities teaching or employers' recruitment. Also, these skills are applicable within any sector. These learnt techniques can be employed in the process of elucidating issues germane to political phenomena, institutions and behaviours of individuals and groups beyond the classroom and the place of work.

Unemployment among the graduates of universities is becoming a growing trend especially within developing countries. This issue is primarily linked to the lack of competitive skills on the job market. In response to this problem, the government within 
REPS

5,3

some of these countries have introduced and developed certain policies as corrective measures. Liew (2012) suggested that universities initiate conversation or dialogue with businesses through what is called university-industry collaboration (UIC). The most efficient-agencies of this collaboration are student internships and research. The engagement between industries and higher-levelled educational institutions will facilitate the exchange of information. This forged dialogue will aid in the process of preparing students for the world of work. One demand highlighted by these industries is for universities to develop "adaptable, flexible and innovative" individuals (Ishengana and Vaaland, 2015).

UIC lessens the disparity between the qualities taught by universities and the necessary skills which are required by the industries. This would be beneficial to provide jobs and improving the economic standpoint of many political science majors who according to Lewis (2017) remain relatively poor during their 20 s.

It is true that many affluent university students look forward to establishing and managing their own businesses, these skills will remain relevant in that sense as these students, who are potential employers, will need to know what to look for in the process of recruiting worthy and productive labourers. There is however a downfall to introducing UIC's within tertiary institutions. This is evident where research projects developed by these industries with which universities are involved usually have capitalistic motives. This detracts the value of learning about the dynamic economy students would be exposed to.

The Wahlke (1991) report outlined a different approach to addressing the issue of preparing political science majors for the work field. In this report, it was highlighted that the issue was not concerned with the pedagogical methods used within the classroom setting; however, the issue was predominantly concerned with the curriculum.

This curriculum was too "diversely conceptualised and organised" and it was necessary to design a curriculum that was more systematic and structured. Nackenoff (2014) states that liberal colleges are more conducive for teaching Political Science students than large universities. She noted that the method of teaching Political Science used in liberal arts colleges and large universities are the same. Essentially, in contrast to the Wahlke Report, the issue is not about the way in which the syllabus of the discipline is put together, rather it is how these institutions challenge students to analyse and understand the discipline. This can enhance their skills of critical thinking, which will further ameliorate their innovative skills, which they can use to institute change.

Kaase (2000) asserts that it is important for political science majors to utilise the internet as an electronic telecommunication channel in their researches. This allows for increase communication among students and lecturers within and across universities through emails and other social media channels. The development of the internet has allowed students to gain access to a limitless database and a plethora of reading, audio and video academic materials, which they can use to conduct researches.

Certainly, this is not an issue within the contemporary space as students of social science generally tap into internet sources to do researches and for the completion of assignments. The problem, however, stand where students often become too reliant on these sources and this stifles their capacity to develop and engage their critical thinking and problem-solving skills. How to differentiate between correct and incorrect information becomes a key skill in such times.

It is also important however, that the curriculum of Political Science has a more narrowed down approach for the teaching of students. More immediacy and emphasis should be placed on teaching students the courses they need to complete their programme rather than postpone them until the second or third year of their study. Noteworthy that more than 71 
per cent of students use loans to fund their tuition. It is therefore important to get them out of universities within the shortest timeframe possible, so they can fulfil these obligations and others as it relates to sustaining themselves and family.

\section{Communicating the value of political science education}

Another innovative method of "communicating the value of political science" degree programmes as suggested by Johnson (2016) is the use of a three pronged approach of integrating the use of active learning methods, innovative pedagogical systems and increasing the use of engagement initiatives. In effect, this recent study postulates that there are distinct benefits to be derived from the deployment of active learning methodologies combined with specific and targeted initiatives to increase participation and awareness of various employability and recruitment programmes to demonstrate and showcase the value of the degree in career areas ranging from public sector, NGOs and private companies.

For instance, the active learning methods focus on student participation and interaction in the process of learning (Archer and Miller, 2011). Political science teaching historically based largely on instructor led delivery methods. Although some pedagogical shift, changes need to be widespread and extensive.

In terms of the learning support tools, Johnson (2016) recommends a mix of Internships and placements, interactive lectures and seminars, electronic teaching resources, audio visuals (Peters and Beeson, 2010) and innovative written and oral assessment tools as suitable means of enhancing the learning process in a twenty-first century context. In terms of teaching methods, specific techniques including the use of role play, simulations and scenarios (Trueb, 2013), discussion groups, reflection and the combination of seminar and lecture formats (hybrid learning) are identified as good ways of enhancing an action based and interactive learning environment.

Some of the potential benefits identified include providing students with opportunity to adopt, develop and practice the attributes and characteristics of real world political players in defined contexts. In addition, active learning affords students with better insights into political process, develops critical thinking and analytical skills, and builds their presentation, communication and self-confidence competencies. Other incremental attributes and competencies include self-management and reflection capabilities.

The second important component of this approach is the recommended use of situated teaching as a means to encouraging broader participation and recruitment initiatives. The objective of doing so is to increase the value proposition of a political science education. This study emphasises the notion that well considered and thoughtful external engagement, recruitment entry and employability exit agenda initiatives can significantly boost awareness and value of degree programmes. This can be achieved by the use of programmes of engagement via creation of feeder schools presentations, career fairs, workshops, regional hubs, coordinated visits, preliminary research training prior to internship period.

The third and most important component of this approach seeks to integrate innovative pedagogical approaches into the curriculum. This embarks upon a closer examination of the core structure and content and uses modules-based methods combined with active learning components to continually offer opportunities for expanding recruitment, employability and teaching.

This modules based method sees the use of lecture-workshop sessions, interactive lectures, group discussions, presentations and practical demonstrations but supported by series of feedback and assessments at completion of each module stage to test effectiveness of the theoretical and practical components (Cohen, 2008). 
REPS

5,3

How HEIs are enhancing value proposition for political science students. A review of select institutions obtained from the Times Higher Ranked (2019) universities was used in identifying best practices used by universities in enhancing the value of political science degree and more importantly in better preparing students for career advancement and employment opportunities for twenty-first century future of work. Table I highlights some of the best value creation practices from a selection of top universities around the globe. Other universities may consider incorporating these best practices in their political science degrees as they prepare their students for the future of work.

\section{Discussion}

Table I was crafted using eight universities obtained from the Times Higher Ranked (2019) universities which offer Political Science Programmes. We investigated how these institutions are altering their political science degree curriculum to enhance its value to students with the ultimate objective of preparing them for the future of work.

A number of recurring themes and methodologies were identified as common strategies being employed by institutions to deliver value benefits for students in a twenty-first century context. Among these were:

- innovative pedagogical methodologies, e.g. active learning and action based learning styles;

- employability, career services, recruitment and engagement initiatives to communicate the value of political science degrees; and

- skills identification, training and attainment of specialised competencies utilising modern tools and technology (e.g. simulations, role play, scenario, peer assessment and audio visual tools, to enhance critical thinking analytical, communication, negotiating and presentation skills).

\section{Future direction for political science students}

It is important for students of political science to recognise that there are wider career prospects opened at their disposal, as this degree, unlike hard sciences, is not limited in application to any set related dimension.

It is not sufficient to state the matching career prospects that are associated with a political science degree, though many are unaware of the significance of their degree within the related and non-related fields. Essentially the dire issue is, but not limited to, where political science majors can find jobs but more so about how will they apply themselves within these positions. It is also important to note that if political science majors were equipped with the right skills the relevance of their degree would not be a question as their place on the job market would have been implied through duties observed while being taught at universities.

Lewis (2017) argued that Political Science undergraduates can perform and apply themselves relatively well within the job market. They noted that these majors earn two thirds more than high school graduates. It was pointed that most of these majors are mostly likely to pursue a graduate degree or doctoral in other related areas.

It was highlighted that the only fields of profession that earn more than Political Science majors with graduate degrees are those who have matriculated in fields of medicine and engineering. The basis of the income generated by these graduates then becomes arguable. Income generated by these students does not directly derive from their first degree in Political Science but rather from their graduate degrees. 


\begin{tabular}{|c|c|c|c|}
\hline Value creation initiatives & University & Link (s) & degree \\
\hline $\begin{array}{l}\text { Yale focuses on the provision of funding for political } \\
\text { science students relating to research thesis projects and } \\
\text { summer internships. They also provide experiential } \\
\text { and practical oriented exposure to political } \\
\text { campaigning, and implementing programmes relating } \\
\text { to social media, community outreach, speech writing } \\
\text { and messaging strategies to enhance students' real life } \\
\text { skills for the future }\end{array}$ & Yale University & $\begin{array}{l}\text { Yale Undergrad PS } \\
\text { programme }\end{array}$ & 243 \\
\hline $\begin{array}{l}\text { Upenn maintains an extensive database of internships } \\
\text { for political science students ranging from government, } \\
\text { international relations, business, finance, law, } \\
\text { journalism, but with a focus on public policy which } \\
\text { provides interaction with public policy professionals. } \\
\text { They also maintain updated statistics and surveys } \\
\text { tracking student employability trends since graduation } \\
\text { indicating future career paths }\end{array}$ & Upenn & $\begin{array}{l}\text { UPenn Career and } \\
\text { Employability Services } \\
\text { UPenn Internship } \\
\text { Opportunities }\end{array}$ & \\
\hline $\begin{array}{l}\text { Student learning outcomes are based on the delivery } \\
\text { and training of specialised skills such as analytical, } \\
\text { communication and presentation skills. Other } \\
\text { competencies such as critical thinking, reflection and } \\
\text { research skills also important for application to 20th } \\
\text { century political issues and challenges }\end{array}$ & $\begin{array}{l}\text { Columbia } \\
\text { University }\end{array}$ & $\begin{array}{l}\text { Columbia Bernard College } \\
\text { of Pol Sci }\end{array}$ & \\
\hline $\begin{array}{l}\text { Duke's political science programme is geared towards } \\
\text { enabling students' good grounding in critical thinking, } \\
\text { communication and analytical skills. More advanced } \\
\text { courses in curriculum is aimed at providing students } \\
\text { interaction with diverse faculty on cutting edge } \\
\text { research to prepare them for jobs in public service, } \\
\text { public administration, communications, journalism and } \\
\text { business fields }\end{array}$ & Duke University & $\begin{array}{l}\text { Duke University Pol Sci } \\
\text { Offerings }\end{array}$ & \\
\hline $\begin{array}{l}\text { Their career advancement services gives personalised } \\
\text { support for internships, job postings and career } \\
\text { development opportunities. The political science } \\
\text { programme focuses on the application of theoretical } \\
\text { political concepts to current events to better understand } \\
\text { how the real world works. They also specialise in } \\
\text { "thematic concentrations" which surround current } \\
\text { twenty-first century issues in public policy, law, } \\
\text { politics, political economy and quantitative analytics }\end{array}$ & $\begin{array}{l}\text { Northwestern } \\
\text { University }\end{array}$ & $\begin{array}{l}\text { Northwestern Pol Sci } \\
\text { Career Paths } \\
\text { Northwestern undergrad } \\
\text { Pol Sci Focus } \\
\text { Northwestern Pol Sci } \\
\text { Concentrations }\end{array}$ & \\
\hline $\begin{array}{l}\text { University of Washington concentrates training on } \\
\text { current subtopic themes in political science such as } \\
\text { political theory, comparative politics, international } \\
\text { relations and political methodology. They also provide } \\
\text { internship opportunities giving students exposure and } \\
\text { interaction to the legislative processes, political } \\
\text { campaigns to hone their writing, people and } \\
\text { negotiation skills }\end{array}$ & $\begin{array}{l}\text { University of } \\
\text { Washington }\end{array}$ & $\begin{array}{l}\text { Univ. of Washington Pol } \\
\text { Sci Objectives } \\
\text { Univ. of Washington } \\
\text { Internships }\end{array}$ & $\begin{array}{r}\text { Table I. } \\
\text { HEIs enhancing the } \\
\text { value of political } \\
\text { science degrees }\end{array}$ \\
\hline
\end{tabular}




\section{REPS \\ 5,3}

\section{4}

Value creation initiatives

Melbourne University takes a global and international perspective to teaching of political science with emphasis on environmental politics, globalisation and international relations, human rights and public policy and civil activism issues to prepare students

specifically for twenty-first century careers in diplomacy and international relations

A special feature of UBC Political Science programme is the European Union (EU) Study Tour and Internship Programme which provides students with face to face, active interaction with policy makers and leaders from leading civil society and diplomatic institutions to participate in workshops, simulations, seminars, engage and observe decision making process in real world setting

McGill places emphasis on political science access and availability to internship practicum. Has extensive database and advanced formal process and guidelines pertaining to internship proposal, evaluation, and internship opportunities comprising its curriculum

Table I. structure

\begin{tabular}{ll} 
University & Link (s) \\
\hline University of & Melbourne Univ. PolSci \\
Melbourne & Overview \\
& Melbourne Politics and \\
& International Studies
\end{tabular}

University of British Columbia

UBC PolSci Placement and Career Services

UBC EU PO1 Sci

Internship Programme

McGill

University

McGill Pol Sci Internships McGill Internship Details

In such a case, an undergraduate degree in Political Science acts as a foundation upon which students advance themselves to attaining more advanced degrees. Therefore, students would not have directly engaged themselves with their undergraduate degree within the world of work.

Many law school applicants have a political science degree. A political science major is seen as strongly aligned with a law degree. Based on a study carried out by the Law School Admission Council, 18 per cent of persons enrolled in law school have a Political Science degree (Gibbs and Wofford, 2016). Students of political Science, like the students of law, would have been exposed to issues concerning state and power, hence the strong correlation between the two.

It was revealed that just over 80 per cent of Political Science majors are granted acceptance into law school; 81 per cent of advisors with a Jurisprudence degree indicated that political science is a "very good" or "excellent" discipline for preparing students to study law; 87 per cent of advisors without a Jurisprudence degree said the same. Additionally, a significant 79 per cent of JD advisors thought that political science is "very good" or "excellent" for preparing students for high academic performance in law schools in comparison to 87 per cent of non-JD advisors who thought the same. Notably, after philosophy, political science was ranked the second highest degree that is thought to prepare students who display interest in pursuing a law degree.

\section{Conclusion}

This paper reflected on specific measures undertaken by institutions globally to equip students with unique skills to enhance the value and relevance of their programmes in the context of an increased technologically driven environment. We used a qualitative approach 
to the review of the literature with implications for practice in examining how universities globally are applying strategies in raising students' skill levels to enhance future workplace value. A review of select institutions obtained from the Times Higher Ranked (2019) universities was used in identifying best practices to prepare a political science student for better employability.

There are some external factors which impedes on the employability of political science majors as they compete within the sphere of the job market. These may include the drastically reduced supply of labour due to globalisation and financial crisis.

We found that contrary to prevailing opinions, a huge skills gap exists for filling the demand for twenty-first century political science related careers in the public and private sector. The attainment of twenty-first century skill sets and the deployment of technology driven teaching and learning methods are vital elements in unlocking the value of political science education and providing students with opportunities to advance their professional and career objectives.

It is, however, important to recognise that there are internal issues within the pedagogical framework of political science. Universities ought to engage in more in-depth discourses on how to effect the relevant changes within this agenda to make political science majors more attractive on the job market. Higher education institutions therefore need to reconsider strategies in the delivery of political science degrees, bearing in mind the increased use of technology and innovative teaching practices. Students also have a role to play in promoting, showcasing their skills and making employers more aware of the value of a political science education, while also committing themselves to a process of lifelong learning.

\section{References}

Ahmad, T. (2015), "Preparing for the future of higher education", On the Horizon, Vol. 23 No. 4, pp. 323-330.

Archer, C.C. and Miller, M.K. (2011), "Prioritizing active learning: an exploration of gateway courses in political science", PS: Political Science and Politics, Vol. 44 No. 2, pp. 429-434.

Baranowski, M. and Weir, K. (2011), "Peer evaluation in the political science classroom", PS: Political Science and Politics, Vol. 44 No. 4, pp. 805-811.

Bok, D. (2006), Our Underachieving Colleges: A Candid Look at How Much Students Learn and Why They Should Be Learning More, Princeton University Press, Princeton.

Bournova, V. (2008), "Traditional v modern teaching methods: advantages and disadvantages of each", available at: https://is.muni.cz/th/f62v8/MgrDiplomkaBoumova.pdf

Breuning, M., Parker, P. and Ishiyama, J.T. (2001), “The last laugh: skill building through a liberal arts political science curriculum", Political Science and Politics, Vol. 34 No. 3, pp. 657-661.

Clark, A. (2011), "Embedding transferable skills and enhancing student learning in a political science research methods module: evidence from the United Kingdom", PS: Political Science and Politics, Vol. 44 No. 1, pp. 135-139.

Clark, A. and Martin, T. (2016), "An audit of transferable skills teaching in UK politics departments", European Political Science, Vol. 15 No. 3, pp. 389-403.

Cohen, M. (2008), "Participation as assessment: political science and classroom assessment techniques", PS: Political Science and Politics, Vol. 41 No. 3, pp. 609-612.

Collins, T.A., Knotts, H.G. and Schiff, J. (2012), "Career preparation and the political science major: evidence from departments", PS: Political Science and Politics, Vol. 45 No. 1, pp. 87-92.

Dezelan, T. and Hafner, D.F. (2014), "First job educational and skill match: an empirical investigation of political science graduates in Slovenia”, Emerald Insight, Vol. 35, pp. 553-575. 
REPS

5,3

Duch, B., Groh, S.E. and Allen, D.E. (2001), The Power of Problem-Based Learning, Stylus Publishing, VT.

DiMaggio, A. (2018), "Is political science relevant? The decline of critical scholarly engagement in the neoliberal era", Poverty and Public Policy, Vol. 10 No. 2, pp. 222-252.

Franco, J. (2018), “A bachelor's degree in political science: are we training researchers, analysts, or both?".

Gibbs, K. and Wofford, C.B. (2016), "Pre-law advising and the political science major: evidence from pre-law advisors", The Teacher, pp. 320-326, doi: 10.1017/s1049096516000287.

Hale, S. (2008), "Innovations in learning and teaching politics", European Political Science, Vol. 7 No. 2, pp. 133-134.

Hill, K.Q. and Myers, R. (2014), "Scientific literacy in undergraduate political science education: the current state of affairs and agenda for action and proposed fundamental benchmarks", PS: Political Science and Politics, Vol. 47, pp. 835-839.

Hurd, P. (1997), Scientific Literacy: New Minds for a Changing World, in Norris, S. (Ed.), Stanford University, CA.

Ishengana, E. and Vaaland, T. (2015), "Can university-industry linkages stimulate student employability", Education + Training, Vol. 58, pp. 18-44.

Ishiyama, J. (2005), "The structure of an undergraduate major and student learning: a cross institutional study of political science programs at thirty-two colleges and universities", The Social Science Journal, Vol. 42 No. 3, pp. 359-366.

Johnson, M. (2016), "Communicating politics: using active learning to demonstrate the value of the discipline", British Journal of Educational Studies, Vol. 64 No. 3, pp. 315-335.

Kaase, M. (2000), "Political science and the internet", International Political Science Review, Vol. 21 No. 3, pp. 265-282.

Lewis, G.B. (2017), "Do political science majors succeed in the labour market?", PS: Political Science and Politics, Vol. 50, pp. 467-472.

Liew, M.S. (2012), "Strategic and tactical approach university-industry collaboration”, Procedia - Social and Behavioral Sciences, Vol. 56, pp. 405-409.

McCarthy, J. and Anderson, L. (2000), "Active learning techniques versus traditional teaching styles: two experiments from history and political science", Innovative Higher Education, Vol. 24 No. 4, pp. 279-280.

Nackenoff, C. (2014), "Why liberal arts colleges can often do political science better that big research institutions: a reflection from an Americanist", Polity, Vol. 46 No. 1, pp. 98-106.

Peters, R. and Beeson, M. (2010), "Reducing the gap between skills sought by employers and developed by education", PS: Political Science and Politics, Vol. 43 No. 4, pp. 773-777.

Rathbun, N. and Rathbun, B.C. (2017), "Teach a student to fish: International relations scholars in a classroom", PS: Political Science and Politics, Vol. 50, pp. 214-220.

Richards, J. (2006), Communicative Language Teaching Today, Cambridge University Press, New York, NY.

Roulston, D. and McCrindle, R. (2018), "Engaging students in research with 'real world' outputs: making an impact outside of the lecture theatre", in Tong, VCH, Standen, A. and Sotiriou, M. (Eds), Shaping Higher Education with Students: Ways to Connect Research and Teaching, UCL Press, London, pp. 208-221.

Sloam, J. (2008), "Teaching democracy: the role of political science education”, The British Journal of Politics and International Relations, Vol. 10 No. 3, pp. 509-524.

Trueb, B. (2013), “Teaching students to write for 'real life': policy paper writing in the classroom”, PS: Political Science and Politics, Vol. 46 No. 1, pp. 137-141.

Wahlke, J. (1991), "Liberal learning and the political science major: a report to the profession", PS: Political Science and Politics, Vol. 24, pp. 48-60. 


\section{Further reading}

American Political Science Association (2011), "Political science in the 21st century", Report of the Task Force on Political Science in the 21st Century ERIC Clearinghouse.

Bobic, M.P. (2005), "Do you want fries with that?" A review of the bachelor's program in political science", Politics and Policy, Vol. 33 No. 2, pp. 349-370.

Bunte, J.B. (2019), "Why do students enroll in political science courses?", PS: Political Science and Politics, Vol. 1, pp. 1-8.

Dunleavy, P. (2010), "New worlds in political science”, Political Studies, Vol. 58 No. 2, pp. 239-265.

Lee, D., Foster, E. and Snaith, H. (2016), "Implementing the employability agenda: a critical review of curriculum developments in political science and international relations in English universities", Politics, Vol. 36 No. 1, pp. 95-111.

Leitner, M. (2018), "Does the economy need political scientists?", Österreichische Zeitschrift Für Politikwissenschaft, Vol. 47 No. 3, pp. 69-70.

Robinson, A.M. (2013a), "The workplace relevance of the liberal arts political science BA and how it might be enhanced: reflections on an exploratory survey of the NGO sector", PS: Political Science and Politics, Vol. 46 No. 1, pp. 147-153.

Robinson, A.M. (2013b), "They want to be global citizens: now what? Implications of the NGO Career arc for students and faculty mentors", Journal of Global Citizenship and Equity Education, Vol. 3 No.1, p. 13.

\section{About the author}

Tashfeen Ahmad expanded his understanding of Psychology at Harvard University and joined The University of the West Indies, Mona, Jamaica, with 10 years of General Management experience. He has taught courses in International Business, Production Management, Operations Management, Quality Management and Change Management. His research work focuses on the future of higher education and learning technologies. Tashfeen Ahmad can be contacted at: mrtashfeen@hotmail.com

For instructions on how to order reprints of this article, please visit our website: 